\title{
Islam, Democracy and the Middle Class
}

\author{
Tengku Ahmad Hazri*
}

Some people have been writing pieces echoing the view that there is a close relationship between democracy and the middle class. Recent times have witnessed two important trends whose close links have often been overlooked: the rise of populism on the one hand and the decline of the middle class on the other. Actually they have something in common in that they are both not good for democracy, and in fact represent a departure from democratic ideals. Populism is unfortunately often a euphemism for the opinions of poor, working class and rural or suburban constituencies, as observed in how election demographic maps often portray populist and far-right candidates as typically winning constituencies in rural areas or non-major cities. The presence of a strong middle class is crucial to democracy because the middle class has the economic base that translates into political independence, thereby enabling them to demand greater rights and accountability from the government. The middle class stands to benefit most from the presence of political institutions and the infrastructure needed to sustain democracy (such as the rule of law and protection of rights, most notably property rights) and hence are most likely to demand them from the state.

Despite all optimism about the middle class, the attachment to wealth as the guarantor of democracy generally and political stability specifically may have adverse consequences on policies towards reforming democracy. For a start, it could translate into a policy of endorsing authoritarian regimes under the pretext that this would be necessary for the gradual establishment of stable economic institutions and a vibrant middle class, before the country could democratise. This is especially pronounced in Muslim-majority countries where politics has been intertwined with religion, and where Islamists play a key role in public life and civil society. Islamists have two striking features that proponents of liberal democracy fear would unleash populism: their ability to reach out to the poor, rural, suburban and working class population, and their efficiency in delivering public services in schools and hospitals, thereby filling up gaps where states have failed. This ability to establish a niche constituency among the working class, rather than being seen as evidence of democratic commitment, has been regrettably framed as testimony of the populism of the Islamists. Diplomats who have queried authoritarian elites have been pressed with the alternative option of these Islamists, and naturally chose the former. Decades of 'strongman' rule, 
nevertheless, has failed to deliver the promised land of democracy and the rule of law; instead it has further entrenched the ruling elite.

Furthermore, such reliance has two other consequences. Firstly, it establishes political stability as being entirely dependent on the economic order and thus, when the economy is in trouble, politics should lapse into a culture of intolerance, with bigotry being normalised as an expected - even "natural"state of affairs. Secondly, it rules out the possibility of grounding economic stability in political stability rather than the other way around. In the light of the first claim, it follows therefore, that the rise of populism and the inimical values that it entails - intolerance, bigotry, xenophobia - has been the direct result of the system itself. The rise of populism in the West has been attributed to several factors, one of which has been the poor economic performance of Western economies since the financial crises of 2008, the crisis in the Eurozone, etc. Economics is the basis of both the marriage and the divorce of European states; it was economics that initially brought European states together as the European Economic Community in 1957. It was also economics that eventually brought them into crisis: the United Kingdom has sought to leave the EU in part because the 'Leave' proponents claim that it will perform better economically if it splits from the bloc. This points to the fact that, if economic crisis results in populism and a decline in political stability in these regimes, it is because the system itself has been designed as such, i.e. to rest political stability on economic stability. Consequently, the decline of democracy is the logical conclusion of economic decline rather than its anomalous implication.

The dependency of political stability on economic stability, or rather, of politics on economics, has deep historical antecedents in European history that are still playing out today. The close relationship between the two has, therefore, led many to think that democratisation and constitutionalism necessitate economic reforms along capitalist lines if political stability is to succeed.

One possible avenue of hope can be seen in how Muslims have understood and rationalised democracy within the parameters of Shari'ah. In contemporary literature on Islam and democracy, the latter has been conceptualised as an institutionalisation of shura (consultation).

Early Islamic history reveals a moral and intellectual, rather than economic, foundation of constitutionalism and the rule of law, evidently illustrated by the pivotal role played by the school known as the ahl al-suffah ("People of the Verandah") in laying down the intellectual foundations of Islamic law. The Qur'an highlights the socio-economic significance of the school when it refers to it as "the poor who are constrained in the way of God" (al-Baqarah 2:271), as explained by commentators such as Ibn Kathir, al-Qurtubi and the 'two Jalals' (Mahalli and Suyuti). The suffah were a group of poor and homeless refugees among the 
Emigrants (muhajirin) who lived in the veranda of the Prophet's Mosque, yet due to the direct responsibility assumed by the Prophet for their welfare and education, some of their members emerged among the earliest scholars of Islam and laid down the early seeds of the rule of law in Islam. The constitutional significance of this school is further underscored when one of its members, Abu Dharr al-Ghifari later emerged as a fierce critic of corruption among the Umayyad ruling elite, for which he was banished to the desert of Rabadha. Abu Dharr thus represents a prototype of the scholar-figure who functioned as a check on the authority of rulers in a constitutional tradition characterised by what Noah Feldman called the "balance of power" between scholars ( "ulama) and rulers. In the heydays of colonial capitalism, the Iranian intellectual Ali Shariati hailed Abu Dharr as a "socialist" whose penchant for social justice inspires the cause of the enfeebled masses of the poor against imperialism, itself made possible by the complicity of commercial capitalism, which ironically is today paraded as the very ingredient needed for democratisation.

\section{Notes}

* Tengku Ahmad Hazri is a Research Fellow at the International Institute of Advanced Islamic Studies (IAIS) Malaysia. He can be contacted at ahmhazri@ iais.org.my. 